\title{
Elimination of Carbon, Nitrogen and Phosphorus in Domestic Wastewater through a Series of Anaerobic and Aerobic Reactors for a Developing Country like Benin
}

\author{
Senandemi E. R. Mahunon', Akuemaho V. O. Akowanou', Martin P. Aina1, \\ Benjamin K. Yao², Dominique K. C. Sohounhloué ${ }^{3}$ \\ ${ }^{1}$ Laboratoire des Sciences et Techniques de l'Eau (LSTE), Université d'Abomey-Calavi (UAC), Cotonou, Benin \\ ${ }^{2}$ Laboratoire de Procédés Industriels, de Synthèse, de l'Environnement et des Energies Nouvelles, Institut \\ National Polytechnique Félix Houphouët-Boigny de Yamoussoukro, Yamoussoukro, Côte d'Ivoire \\ ${ }^{3}$ Laboratoire d'Etude et de Recherche en Chimie Appliquée (LERCA), Ecole Polytechnique d'Abomey-Calavi \\ (EPAC), Université d'Abomey-Calavi (UAC), Cotonou, Bénin \\ Email: ainamartin72@gmail.com
}

Received 10 April 2015; accepted 14 June 2015; published 17 June 2015

Copyright (C) 2015 by authors and Scientific Research Publishing Inc.

This work is licensed under the Creative Commons Attribution International License (CC BY). http://creativecommons.org/licenses/by/4.0/

(c) (7) Open Access

\begin{abstract}
Waste water treatment in order to preserve water resources is one of the major concerns in developing countries. This study aims to test the operating effectiveness of a pilot designed on a basis of several laboratory experiments, which consists of an anaerobic and aerobic pond in series. The test was performed through monitoring global parameters of pollution. The results of the analysis of these parameters indicate an elimination of $91 \%$ of suspended solids, $68 \%$ of COD, $77 \%$ of $\mathrm{BOD}_{5}, 61 \%$ of nitrate and $81 \%$ of phosphorus. It was also noticed that the anaerobic pond removes most, carbonaceous organic materials and especially suspended matters; and the aerobic pond most, nitrogen and especially phosphorus. This study reveals the effectiveness of the series connection of an anaerobic and aerobic pond for domestic wastewater treatment.
\end{abstract}

\section{Keywords}

Wastewater, Anaerobic/Aerobic Pond, Pilot

\footnotetext{
How to cite this paper: Mahunon, S.E.R., Akowanou, A.V.O., Aina, M.P., Yao, B.K. and Sohounhloué, D.K.C. (2015) Elimination of Carbon, Nitrogen and Phosphorus in Domestic Wastewater through a Series of Anaerobic and Aerobic Reactors for a Developing Country like Benin. American Journal of Analytical Chemistry, 6, 577-584.
} 


\section{Introduction}

Human activities give rise to a wide variety of wastes which must be treated before being discharged into the environment. These wastes may, individually or collectively pollute and contaminate the water resource. Fella et al. [1] affirm that the deficiency in their management remains one of the main factors of disease transmission and environmental degradation. But the difficulties related to the management of these wastes and their sanitation become increasingly recurrent in the world and constitute for the developing countries a very worrying and embarrassing environmental issue. It is more alarming in urban areas due to population growth [2].

In Benin, where little importance is given to the coverage of sanitation services compared to the coverage of water supply services and even less to the purification [3], the problem is more dramatic. But inexpensive systems in terms of implementation and whose maintenance is relatively easy are more adapted to developing countries [4]. To overcome this situation, there is a need to think about affordable and effective wastewater treatment method.

Several treatment methods are developed around the world to treat domestic wastewater (activated sludge, rotating biological, lagoons, assessed cultures, oxyternes etc.). But those adapted to developing countries, are inexpensive in terms of implementation and their maintenance is relatively easy. Thus, the lagoon is considered to be the most suitable technology for wastewater treatment in the climate context of sub-Saharan countries (strong solar radiation, long hours of sunshine) [5]. To avoid stratification problems which negatively affect the proper functioning of lagoons purification stations, a constant mechanical stirring is recommended. Most of these techniques adapted to our realities often use anaerobic and aerobics ponds. To obtain better process stability, some researchers have been focusing on combinations of anaerobic and aerobic ponds [6]. And this approach seems to be a good option for domestic wastewater treatment in developing countries like Benin.

Prior to the use of this kind of treatment, a study of the efficiency of carbon, nitrogen and phosphorus removal using two different reactors anaerobic and aerobic was conducted.

\section{Materials and Methods}

This study was conducted on wastewaters from a specific septic tank on the University of Abomey-Calavi in Benin which is the Canadian F building septic tank (one of the students' residences). The Choice was made based on the high concentration of carbonaceous pollutants [7].

\subsection{Experimental Setup}

The study was conducted in continuous reactors and forced-ventilation mode. The experimental pilot consists of an anaerobic reactor with a capacity of $20 \mathrm{~L}$ and a working volume of 18 liters which is connected to an aerobic reactor where a forced-ventilation system is used for aeration (Figure 1). The working volume of the aeration reactor was 12 liters. The aeration is provided by a cooling module consisting of a pale of diameter $2 \mathrm{~cm}$, fixed to a shaft which is itself driven by a motor. The aeration is not subject to a regulation but is sufficient to saturate the medium. The aerobic reactor is itself connected to a clarifier with a capacity of 5 liters. The clarifier was almost serving as a secondary decanter due to its form, which is the one of a decanter. The pilot was fed by a peristaltic pump Master Flex Type L/S “drive console” with a type of head Easy-Load II, 7518-10 model. The inflow feeding rate was $1.6 \mathrm{ml} / \mathrm{s}$.

\subsection{Analytical Methods}

The pilot evaluation was performed through a sampling technique. The sampling technique adopted is to take samples every 3 hours from the anaerobic pond, every 30 minutes for 2 hours from the aeration tank (aerobic tank) and every 20 minutes for 40 minutes from the clarifier. The samples are stored at $4^{\circ} \mathrm{C}$ before being analyzed within 24 hours. Table 1 shows all measured parameters.

\section{Results and Discussions}

\subsection{Wastewater Characterization}

The first step was to characterize raw water from the septic tank. Table 2 present the results of the characterization. The analysis of this table reveals an averag level of Chemical Oxygen Demand (COD) in the wastewater 


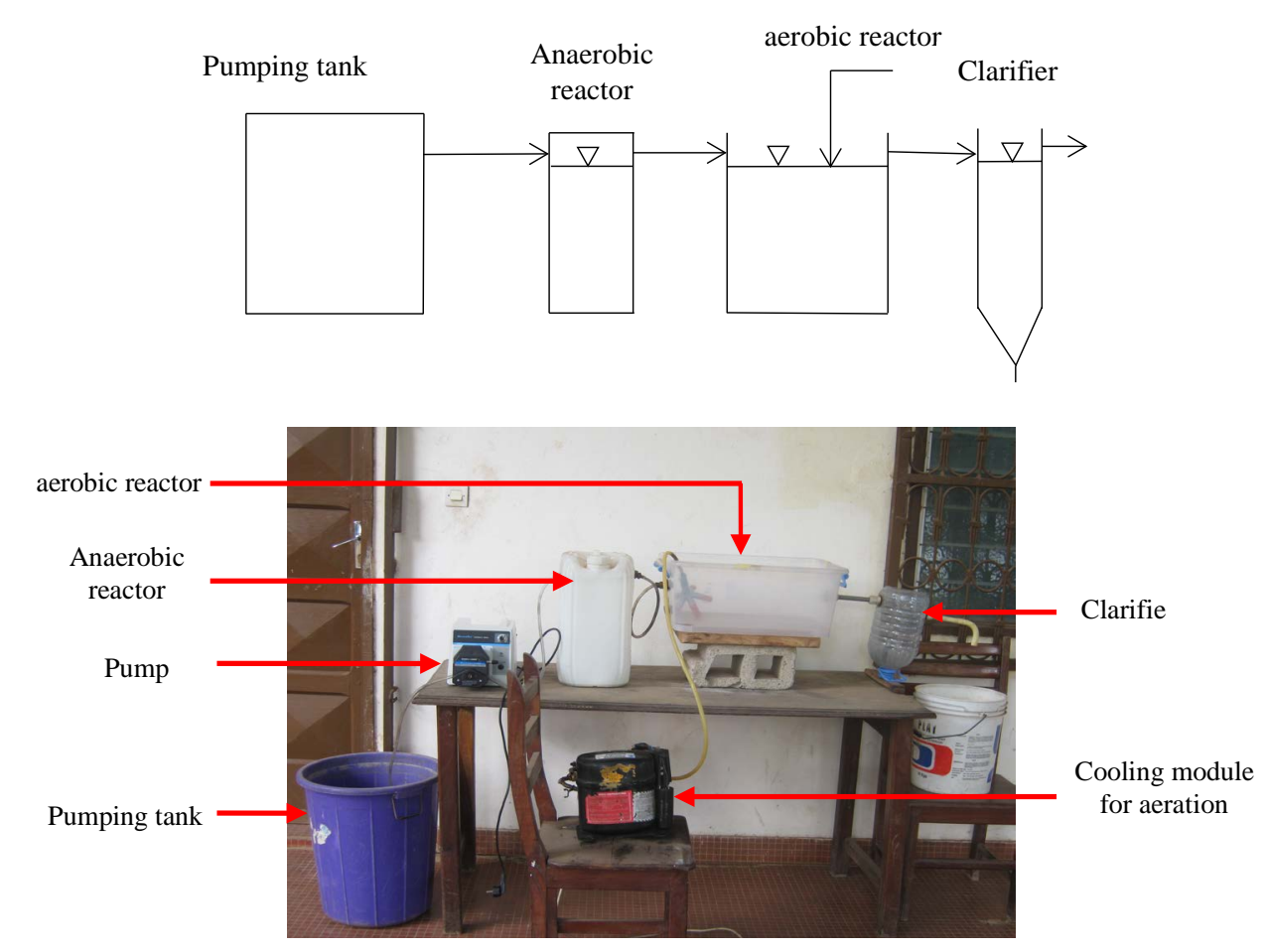

Figure 1. Anaerobic aerobic reactors.

Table 1. Measurement method of physic-chemical parameters.

\begin{tabular}{ccc}
\hline Parameters & Measurement Method & Standard \\
\hline $\mathrm{pH}$ & Potentiometric & NFT 90-008 \\
Dissolved Oxygen $\left(\mathrm{O}_{2}\right), \mathrm{mg} / \mathrm{l}$ & Electrochemical & NFT 90-106 \\
Conductivity $(\chi), \mu \mathrm{S} / \mathrm{cm}$ & Electrochemical & NF EN 27888 \\
Turbidity (Turb), NTU & Light Scattering & NFT 90-033 \\
Chemical Oxygen Demand (COD), mg/l & Volumetric & NFT 90-101 \\
Biochemical Oxygen Demand (BOD $), \mathrm{mg} / \mathrm{l}$ & Manometric & NF EN 872 \\
Total Suspended Solids (TSS), mg/l & Filtration & NF EN 25663 \\
$\mathrm{NTK}^{-}$ & Mineralization Using Selenium & NFT 90-015 \\
$\mathrm{NH}_{4}^{+}$ & Nesssler & NFT 90-012 \\
$\mathrm{NO}_{2}^{-}$ & Absorption Molecular Spectometric & T 90-045 \\
$\mathrm{NO}_{3}^{3--}$ & Absorption Molecular Spectometric & NFT 90-023 \\
\hline
\end{tabular}

from the Canadian F building septic tank which is equal to $530 \mathrm{mg} / \mathrm{l}$ with an average ratio of COD = 2.3 which reflects the biodegradability of the effluent and an average concentration of TSS which is equal to $190 \mathrm{mg} / \mathrm{l}$ (Table 2). This effluent, also verifies the ration $\mathrm{BOD}_{5}: \mathrm{N}: \mathrm{P}(100: 45: 2)$, which facilitates the growth of bacteria and explains the choice of the biological treatment process used [8]. According to its composition, the wastewater from the Canadian F building septic tank on the University of Abomey can be classified as a domestic wastewater moderately loaded.

\subsection{Physico-Chemical Parameters}

The conductivity values obtained in the aerobic tank are from $690 \mu \mathrm{S} / \mathrm{cm}$ to $684 \mu \mathrm{S} / \mathrm{cm}$. These values could be explained by the sedimentation of the mineral salts that are mixed in the deposited sludge. 
Table 2. Characterization of wastewater used for the experimentation.

\begin{tabular}{ccccc}
\hline Parameters & Max & Min & Average & Precision \\
pH & 6.34 & 6.15 & 6.25 & \pm 0.001 \\
Temperature, ${ }^{\circ} \mathrm{C}$ & 29.1 & 28.1 & 28.6 & \pm 0.1 \\
Dissolved Oxygen, mg/l & 0.80 & 0.50 & 0.65 & \pm 0.01 \\
Conductivity, $\mu$ S/cm & 828 & 552 & 690 & \pm 1 \\
Turbidity, NTU & 284.00 & 250.90 & 267.25 & \pm 0.01 \\
Total Suspended Solids (TSS), mg/l & 200 & 180 & 190 & \pm 1 \\
Biochemical Oxygen Demand (BDO $), \mathrm{mg} / \mathrm{l}$ & 221 & 220 & 221 & \pm 1 \\
Chemical Oxygen Demand (COD), mg/l & 551 & 508 & 530 & \pm 1 \\
$\mathrm{NTK}^{-}$ & 95 & 46 & 70.5 & \pm 1 \\
$\mathrm{NH}_{4}^{+}$ & 63 & 31 & 47 & \pm 1 \\
$\mathrm{NO}_{2}^{-}$ & 0.150 & 0.006 & 0.078 & \pm 0.001 \\
$\mathrm{NO}_{3}^{-}$ & 9.2 & 9.0 & 9.1 & \pm 0.01 \\
$\mathrm{~N}_{\mathrm{G}}$ & 104.21 & 55.15 & 79.68 & \pm 0.01 \\
$\mathrm{P}$ & 4.30 & 4.02 & 4.16 & \pm 0.01 \\
\hline
\end{tabular}

Min: Minimum; Max: Maximum;

For the $\mathrm{pH}$, there is a slight increase in treated water (6.71) and raw wastewater (6.25), which is probably due to the chemical and/or biological reactions involved in the release of acid ions or consumption of basic ions. The same observation about the increase was done by Rejsek [9]. As an example, we can mention the reactions of nitrification that cause the acidification of the environment since the effluent comes from a basin (aeration ba$\sin )$.

The temperature obtained at the entrance and exit of the driver are $28.6^{\circ} \mathrm{C}$ and $27.95^{\circ} \mathrm{C}$, respectively, they are very close; in these conditions we talk about the constancy of that raw water which is probably related to the transportation conditions of sewage to the driver. These values are acceptable and remain below the standard set by WHO $[10]$ at $30^{\circ} \mathrm{C}$.

\subsection{Organic Matter}

At the exit of the pilot, a MES value is recorded in accordance with the standards set at a maximum of $18 \mathrm{mg} / \mathrm{l}$. The sharp drop in MES content of the treated water would be due to the elimination of the particles by the adsorption of the suspended solids on the biological flocs, on one hand and on the other hand, the good sedimentation at the clarifier. These same observations were made by Rejsek [9]. The rate of decrease in the TSS content after treatment is shown in Figure 2 and is of the order of 91\%. This rate is the same order of magnitude as that recommended by Rejsek [9] to be qualified as residual waste water (90\%). Only the anaerobic pond contributes to almost $71 \%$ in the rate of reduction observed on solids suspensions. This contribution from the anaerobic pond is of the same order of magnitude as that of a primary clarifier (70\%) with a few hours of residence time by Effébi [11].

The measurement of the Biochemical Demand in Oxygen evaluates the content in biodegradable organic matter of water, thus its degree of pollution [12]. The value of $\mathrm{BOD}_{5}$ in raw wastewater $(221 \mathrm{mg} / \mathrm{l})$ confirms the conclusion drawn in the characterization table and that obtained by CNERU [13], which classify such a wastewater as a moderately loaded wastewater. But on the other hand, for the treated water, the $\mathrm{BOD}_{5}$ is $50 \mathrm{mg} / \mathrm{l}$ which shows an efficiency of $77 \%$ (Figure 3) where the anaerobic pond contributes to almost $63 \%$. This value reduction of $\mathrm{BOD}_{5}$ according to Cardot [14] is due to the activity of purifying microorganisms that provide the degradation and transformation of the organic matter. These microorganisms therefore favor the elimination of organic pollution through the settling and sedimentation of sludge responsible for the elimination of almost all the $\mathrm{BOD}_{5}$.

As for the COD, it corresponds to the whole organic content whether they are biodegradable or not. There is therefore a $\mathrm{COD}>\mathrm{BOD}_{5}$ because bacteria do not oxidize all organic components especially those chemically 


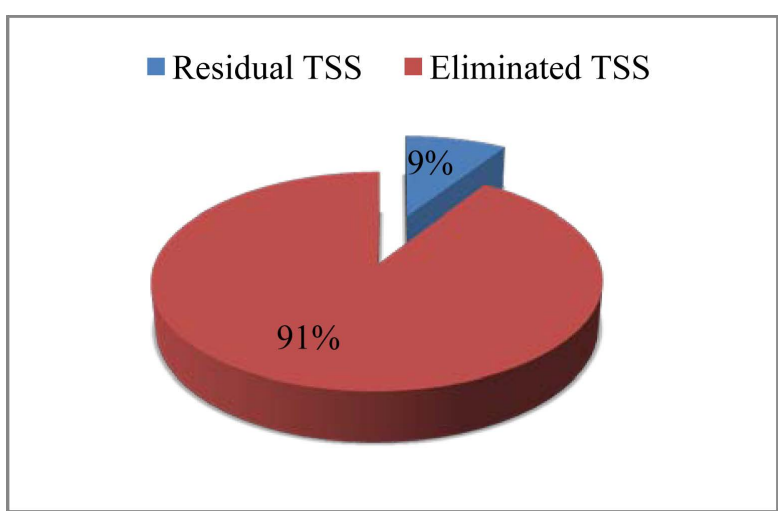

Figure 2. TSS removal rate.

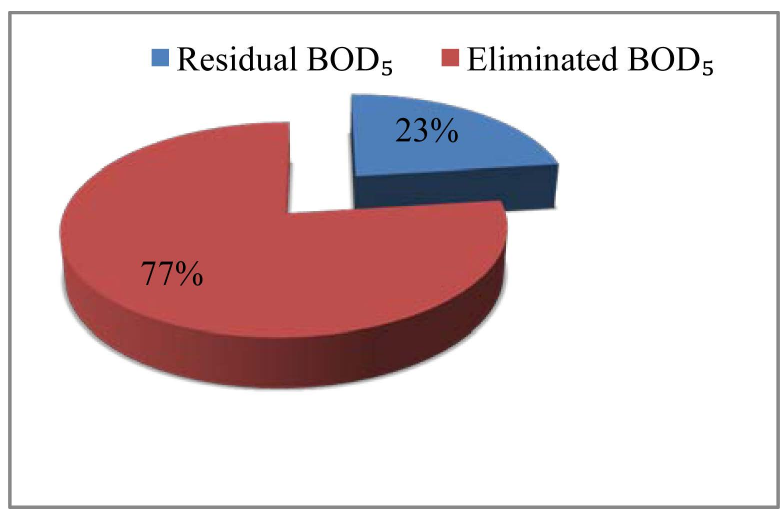

Figure $3 . \mathrm{BOD}_{5}$ removal rate.

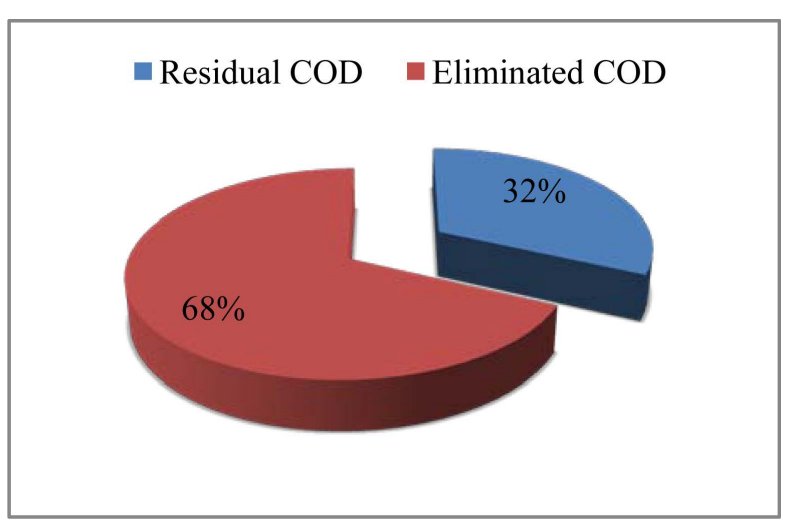

Figure 4. COD removal rate.

stable [12]. For COD, raw water content is $530 \mathrm{mg} / \mathrm{l}$. We have at the output of the station the COD value which is equal to $172 \mathrm{mg} / \mathrm{l}$ with an efficiency of $68 \%$ (Figure 4) where the anaerobic tank provides $46 \%$.

Overall, the carbon pollution purges efficiency, COD (68\%), BOD 5 (77\%) and MES (91\%) are satisfactory and the anaerobic pond contributes more in the carbon pollution removal efficiency in the process Figure 5.

\subsection{Nutrients}

The low nitrate content $(9.1 \mathrm{mg} / \mathrm{l})$ obtained in the raw water is linked to the fact that the nitrogen in domestic wastewater is essentially a human originated one, and is mainly in the organic form by Chocat [15]. It is thus under the ammoniacal and organic forms that the nitrogen is present in the effluent to be treated, which confirms the results in literature by Putz [16]. The increased nitrate content observed during treatment would be explained 


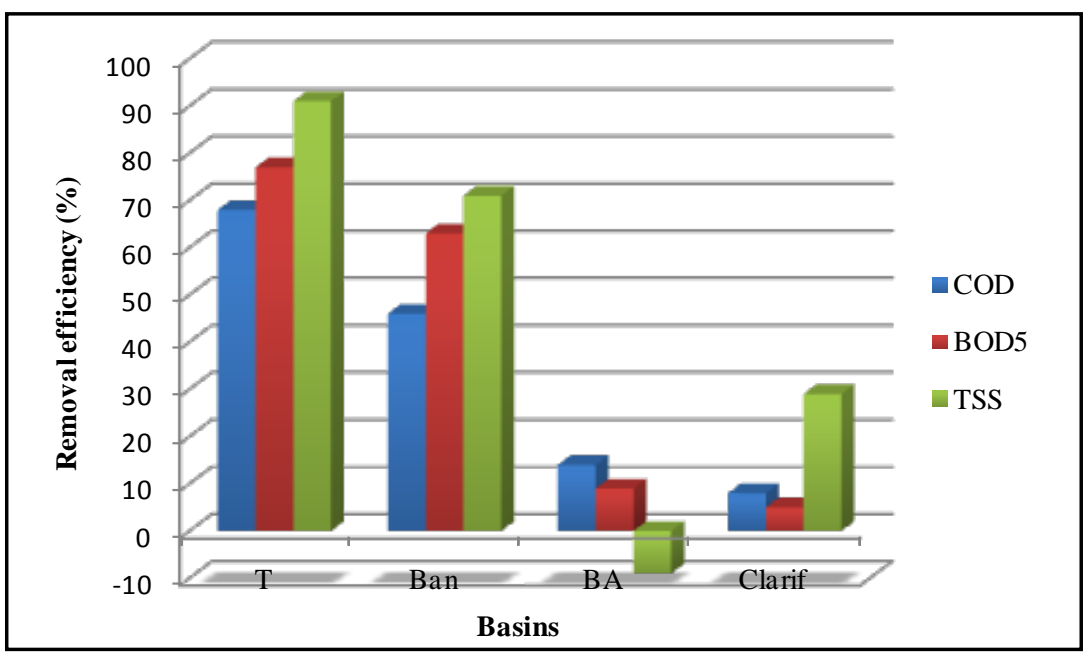

Figure 5. Removal efficiency of carbon pollution. (T) total, (Ban) Anaerobic pond (BA) Aeration pond, (Clarif) Clarifier.

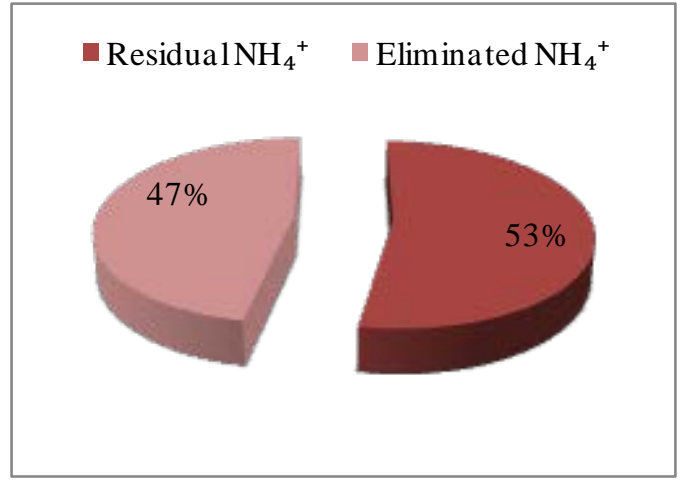

Figure 6. $\mathrm{NH}_{4}^{+}$transformation rate.

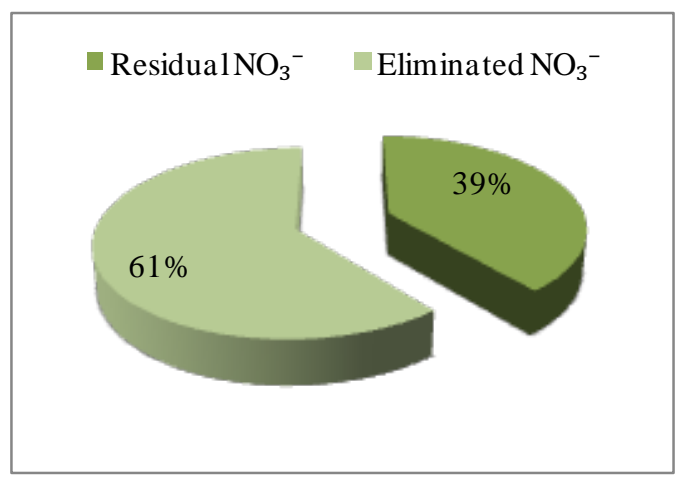

Figure 7. $\mathrm{NO}_{3}^{-}$removal rate.

by the presence of the nitrification of the organic nitrogen phenomenon resulting in the oxidation of the ammoniacal nitrogen. The efficiency of conversion of ammonium ion is 47\% (Figure 6) which is low, which also explains the low rate of nitrification 39\% (Figure 7).

But on the other hand, as for the phosphorus, we note a net phosphorus uptake by microorganisms in the environment causing the decline of the latter from $4.16 \mathrm{mg} / \mathrm{l}$ to $0.7 \mathrm{mg} / \mathrm{l}$, thus an abatement rate of $81 \%$ (Figure 8 ). This result seems to be satisfactory in terms of concentration as compared to the standards ( $<2 \mathrm{mg} / \mathrm{l})$. 


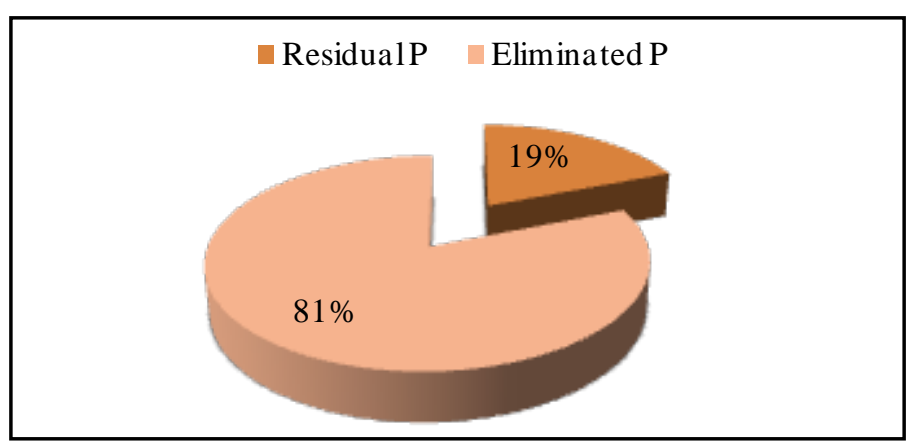

Figure 8. P removal rate.

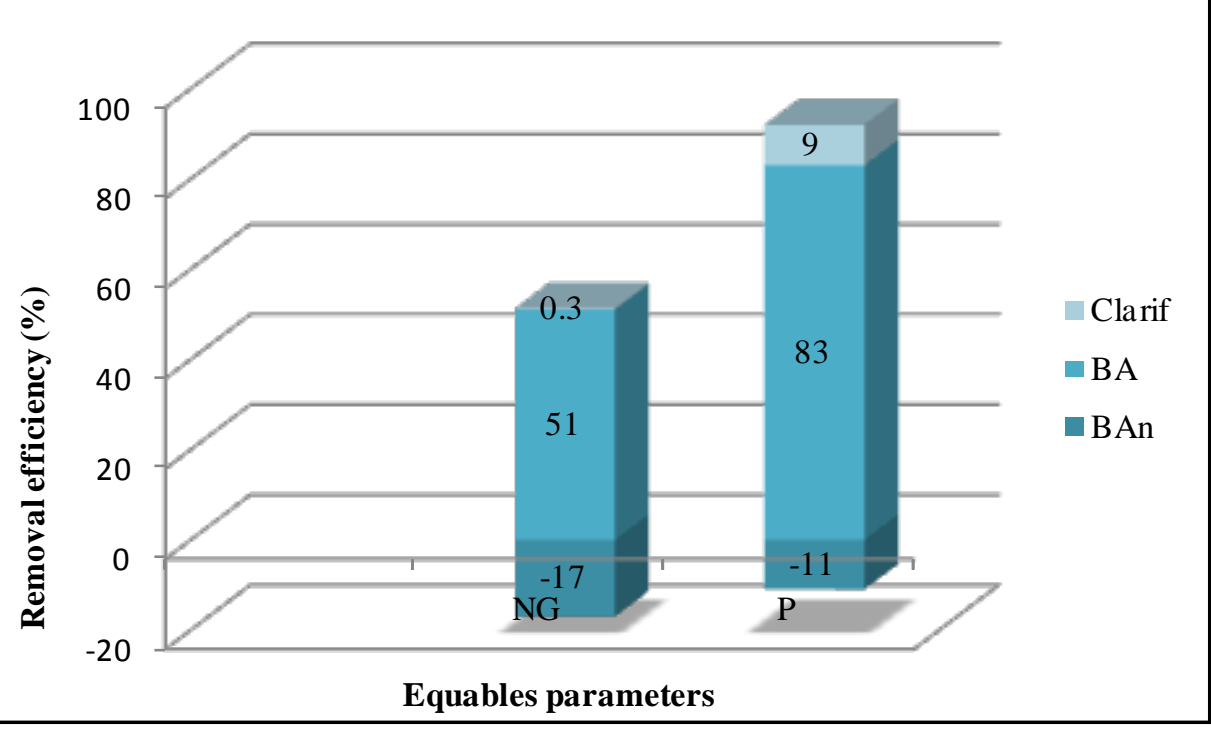

Figure 9. Removal of $\mathrm{N}_{\mathrm{G}}$ and $\mathrm{P}$ for each pond and their contribution in the total removal efficiency of each element.

Overall, the nitrogen pollution removal efficiency is unsatisfactory while that of phosphorus pollution is very satisfactory. The comparison of purification performance parameters $\left(\mathrm{N}_{\mathrm{G}}\right.$ and $\left.\mathrm{P}\right)$ shows that the aerobic tank contributes most to the nitrogen and phosphorous pollution removal efficiency of the process Figure 9.

\section{Conclusion}

Using the pilot which consists of an anaerobic and aerobic pond in series gives a good performance through the elimination of various parameters such as $\mathrm{COD}, \mathrm{BOD}_{5}, \mathrm{P}$ and TSS with respective efficiencies of $67 \%$, $77 \%$, $81 \%$ and $91 \%$. Thus, the anaerobic tank exhibits an excellent carbon material removal efficiency with settling as main process of elimination. And the aerobic tank (aeration) has a very good return for the elimination of phosphorus material and nitrogen using respectively assimilation and nitrification.

\section{References}

[1] Fella, H., Rabia, Z., Mohand, S. H., Smain, M., Abdelmalek, B. and Hichem K. (2012) Environnement : Epuration des eaux usées domestiques par les boues activées: Etude de la performance d'une STEP dans wilaya de Médié (NordOuest de l'Algérie). ScienceLib.

[2] Kengne, N.I.M. (2000) Evaluation d'une station d'épuration des eaux usées domestiques par lagunage macrophytes à Yahoundé: Performances épuratoires, développement et biocontrôle des Diphtères Culicidae. Université de Yahoundé I. 153p.

[3] Livre bleu Bénin: L’eau, assainissement, la vie et le développement humain durable. 103p. 
[4] Dovonou, E.F. (2005) Gestion de l'environnement Assainissement des eaux usées: Contribution à l'élaboration de la politique d'assainissement des eaux usées domestiques par la SONEB au Bénin: Cas de la ville de Cotonou. DSS. 69p.

[5] Maiga, A.H., Konaté, Y., Wethe, J., Denyigba, K. and Togola, L. (2006) Performances épuratoires d'une filière de trois étages de bassinss de lagunage à microphytes sous climat sahélien: Cas de la station de traitement des eaux usées de l'EIER. Sud Sciences \& Technologies, 14, 4-12.

[6] Magnaye, F.A., Gaspillo, P.D. and Auresenia, J.L. (2009) Biological Nitrogen and COD Removal of Nutrient-Rich Wastewater Using Aerobic and Anaerobic Reactors. J. Water Resource and Protection, 1, 376-380. http://dx.doi.org/10.4236/jwarp.2009.15045

[7] Kpondjo, N.M., Youssouf, A., Aina, M.P., Agbla, S., Adjahatodé, F. and Sohounhloue, D.K.C. (2012) Statistical Analysis for the Assessment of Water Treatment Parameters by Three Macrophytes Identified. International Journal of Biosciences (IJB), 2, 65-74.

[8] EL Hafiane, F. and EL Hamouri, B. (2002) Performances d'un système anaérobie à deux phases dans l'épuration des eaux usées domestiques sous climat méditerranéen. El Hafiane \& El Hamouri: Performances du SADP. Actes Inst. Agron. Vet. (Maroc), 22, 133-141.

[9] Rejsek, F. (2002) Analyse des eaux: Aspects réglementaires et techniques. Scéren (CRDP AQUITAINE). Coll. Biologie technique. Sciences et techniques de l'environnement. 360p.

[10] WHO (2010) Organization, W.H., Water, Sanitation and Hygiene Links to Health Facts and Figures-Updated November 2004. Geneva.

[11] Kôkôh, E.R. (2009) Lagunage anaérobie: Modélisation combinant la décantation primaire et la dégradation anaérobie. Thèse, Université de Liège Campus d’ARGON, Département des Sciences et Gestion de l'Environnement Unité Assainissement de l'Environnement, 235p.

[12] Djermakoye, M.M.H. (2005) Les eaux résiduaires des tanneries et des teintureries: Caractéristiques physico-chimiques, bactériologiques et impact sur les eaux de surface et les eaux souterraines « Mali ». Thèse Pour obtenir le grade de Docteur en Pharmacie. Faculté de Médecine, de Pharmacie et d’Odonto-stomatologie. Université de Bamako. 135p.

[13] CNERU (1980) Etudes et réalisations en urbanisme. Recueils sur la zone industrielle d’El Hadjar, 42p.

[14] Cardot, C. (1999) Génie de l'environnement: Les traitements de l'eau. Ellipses, Paris, 247p.

[15] Chocat, B. (coordonnateur) (1997) Encyclopédie de l’hydrologie urbaine et de l'assainissement. Tec \& Doc, Lavoisier, Paris, 1136p.

[16] Putz, P. (2009) Rapport d'application. Analyse de laboratoire et Analyse en continu Eléments nutritifs. Composées Azotés. HACH LANGE Rapport d'application, 4p. 